\title{
PARASITES OF YOUNG BALTIC COD, GADUS MORHUA CALLARIAS L. IN THE GULF OF PUCK, POLAND
}

\author{
Małgorzata PILECKA-RAPACZ ${ }^{*}$, Ewa SOBECKA ${ }^{2}$ \\ ${ }^{1}$ Division of General Zoology, University of Szczecin, Poland \\ ${ }^{2}$ Division of Fish Diseases, Agricultural University of Szczecin, Poland
}

Pilecka-Rapacz M., Sobecka E., 2004. Parasites of young Baltic cod, Gadus morhua callarias L. in the Gulf of Puck, Poland. Acta Ichthyol. Piscat. 34 (2): 235-240.

Background. The hitherto published records of the parasite fauna of Baltic cod, Gadus morhua callarias cover commercially-caught adult fish. The aim of this study was to determine the composition of the parasite fauna of young Baltic cod, the relevant infection parameters and to relate those data to published records on the diet of cod.

Material and Methods. This survey was carried out on 154 young cod, caught in May and June 2002 in the Gulf of Puck, the Baltic Sea, Poland. The fish were examined using standard methods applied in parasitology.

Results. No external parasites were found. In the digestive tracts of $58 \mathrm{cod}, 3$ species of parasites belonging to 2 higher taxa (Nematoda and Acanthocephala) were found. The dominant parasite was Echinorhynchus gadi Zoega in Müller, 1776. The mean abundance ranged from 0.15 to 2.75 . The prevalence ranged from $14.6 \%$, in the smallest fish, to $66.7 \%$ in the larger ones. Only two acanthocephalan specimens of Pomphorhynchus laevis (Zoega in Müller, 1776) and five nematode larvae of Hysterothylacium aduncum (Rudolphi, 1802) were found.

Conclusion. The parasite fauna of young Baltic cod is significantly sparser than in larger fish examined by other authors. It is suggested that the occurrence of the species found, can be related to the composition of diet available.

Key words: fish, cod, Gadus morhua callarias, Gadidae, parasites, Gulf of Puck, Baltic Sea, Poland.

\section{INTRODUCTION}

Parasites of Baltic cod, Gadus morhua callarias L. were reported by Markowski (1933), Rutkowicz (1963), and Rokicki (1975). Those studies covered larger, commercially-caught fish, and mainly the internal parasites were described. Among the reported 22 metazoan species of parasites, the acanthocephalan Echinorhynchus gadi Zoega in Müller, 1776 was a predominant species (Studnicka 1965, Buchmann 1988, 1995, Reimer 1995).

${ }^{*}$ Correspondence: Dr Małgorzata Pilecka-Rapacz, Katedra Zoologii Ogólnej, Wydział Nauk Przyrodniczych, Uniwersytet Szczeciński, ul. Felczaka 3c, 71-412 Szczecin, Poland, e-mail: rapacz@univ.szczecin.pl 
The aim of the present study was to examine which parasites can be found as early as in the young age groups of cod (which has not reached the market size), with particular reference to the issue of E. gadi dominance. Another objectives of this study were to compare the diversity of parasites with the available data on older-cod parasites and to relate the presence of parasites to the literature data on the diet composition of cod inhabiting the southern Baltic Sea.

\section{MATERIAL AND METHODS}

This parasitological survey was carried out on 154 young cod, caught with a fyke net as a by-catch during commercial fishing in the Gulf of Puck in May and June 2002. Fish were sampled three times, near Jastarnia (4 May, 58 individuals; 14 May, 51 ind., and 5 June, 44 ind.) at a depth of about 6 meters. The samples were iced and promptly delivered to a laboratory at the Division of General Zoology, University of Szczecin. There, after being measured and weighed cod underwent parasitological examination, focused on the skin, gills, fins, spleen, kidney, body cavity, and the digestive tract contents. The parasites found were preserved in $70 \%$ ethyl alcohol or glycerine-alcohol mixture and subsequently identified.

\section{RESULTS}

The cod examined were divided into eight length classes (Table 1). No external parasites were found. A total of 3 parasite species were recovered from the digestive tracts and digestive tract walls of 58 fish examined (5 nematodes Hysterothylacium aduncum L4; 150 adult acanthocephalans Echinorhynchus gadi; and 2 Pomphorhynchus laevis). The infection data are presented in Table 1.

Table 2 presents the infection parameters of Echinorhynchus gadi in cod. 35.7\% of the cod population was infected with $E$. gadi. The mean abundance for each length class was low and ranged from 0.15 for the smallest fish up to 2.75 for the fish in the 21-22.9 cm length class. The mean intensity of infection was low; the highest was recorded in cod in the $21.0-22.9 \mathrm{~cm}$ length class.

\section{DISCUSSION}

Earlier studies on cod fished in the southern Baltic show relatively low abundance of nematode infections. The principal species recorded were Contracaecum osculatum (Rudolphi, 1802), Anisakis simplex (Rudolphi, 1809, det. Krabbe, 1878), Capillaria gracilis (Bellingham, 1840), and Hysterothylacium aduncum (Rudolphi, 1802) (cf. Rokicki 1975, Myjak et al. 1994, Morozińska-Gogol 1995, Reimer 1995).

In the present study $H$. aduncum was found in low numbers. Experimental infections carried out by Køie (1993) demonstrate that that $H$. aduncum third-stage larvae developed in the haemocoel of calanoid and harpacticoid copepods, and as well in Mysidacea, Amphipoda, Isopoda, bristle worms, and molluscs. In the natural 
Table 1

Parasites found in different length classes of young Baltic cod from the Gulf of Puck

\begin{tabular}{ccccccc}
\hline & & \multicolumn{4}{c}{ Number of fish infected with } \\
\cline { 3 - 6 } $\begin{array}{c}\text { Length class } \\
{[\mathrm{cm}]}\end{array}$ & $\mathrm{N}^{*}$ & $\begin{array}{c}\text { Number } \\
\text { of fish infected }\end{array}$ & E. gadi & H. aduncum & E. gadi & E. gadi \\
\hline $13.0-14.9$ & 41 & 8 & 6 & 2 & 1 & 1 \\
$15.0-16.9$ & 44 & 12 & 10 & & 1 \\
$17.0-18.9$ & 24 & 12 & 12 & & \\
$19.0-20.9$ & 11 & 7 & 7 & & 1 \\
$21.0-22.9$ & 8 & 4 & 3 & & \\
$23.0-24.9$ & 15 & 8 & 8 & & \\
$25.0-26.9$ & 8 & 4 & 3 & & \\
$>27.0$ & 3 & 2 & 1 & & \\
\hline
\end{tabular}

* Number of fish examined.

Table 2

Infection parameters of Echinorhynchus gadi in cod

\begin{tabular}{ccccccc}
\hline $\begin{array}{c}\text { Fish length class } \\
{[\mathrm{cm}]}\end{array}$ & $\begin{array}{c}\text { Number of fish } \\
\text { infected }\end{array}$ & $\begin{array}{c}\text { Number } \\
\text { of parasites }\end{array}$ & $\begin{array}{c}\text { Prevalence } \\
{[\%]}\end{array}$ & $\begin{array}{c}\text { Intensity } \\
\text { range }\end{array}$ & Abundance & $\begin{array}{c}\text { Mean intensity } \\
\text { of infection }\end{array}$ \\
\hline $13.0-14.9$ & 6 & 6 & 14.6 & 1 & 0.2 & 1 \\
$15.0-16.9$ & 12 & 36 & 27.3 & $1-12$ & 0.8 & 3 \\
$17.0-18.9$ & 12 & 26 & 50.0 & $1-5$ & 1.1 & 2.2 \\
$19.0-20.9$ & 7 & 19 & 63.3 & $1-8$ & 1.7 & 2.7 \\
$21.0-22.9$ & 4 & 22 & 50.0 & $1-15$ & 2.8 & 5.5 \\
$23.0-24.9$ & 8 & 25 & 53.3 & $1-11$ & 1.7 & 3.1 \\
$25.0-26.9$ & 4 & 12 & 50.0 & $1-8$ & 1.5 & 3 \\
$>27.0$ & 2 & 4 & 66.7 & $1-3$ & 1.3 & 2 \\
\hline
\end{tabular}

environment of the Baltic Sea the third-stage larvae of this species were recorded in many planktonic organisms (Fagerholm 1982, 1987).

It has been determined, the diet of 15-cm-long cod in the southern Baltic Sea consists mainly of representatives of Polychaeta, Mysidacea, and Amphipoda. Mysis mixta (Mysidacea) plays the main role in the diet of cod from 8 to $25 \mathrm{~cm}$ (Mańkowski 1959). Consequently, the fish feeding on zooplankton can get infected with nematode larvae. The percentage of zooplankton decreases with increased fish length (Table 3). 
The predominant parasite in the fish of the present study was $E$. gadi. Abundance was low in fish shorter than $19 \mathrm{~cm}$ but reaching a peak in fish $21-22.9 \mathrm{~cm}$ long, and then, although based on a limited number of fish, apparently decreased again (Table 2). This tendency could be related to a change in the composition of the diet of the fish (Table 3). The daily diet of young fish constitutes $1 \%$ of their body weight, and its composition is very variable. The amphipods Gammarus oceanicus, G. locusta, and Pontoporeia femorata are often found in the diet contents of small cod (Załachowski 1977). These species are often intermediate hosts for E. gadi (cf. Valtonen et al. 1983). The daily diet composition of adult fish is less variable, and comprises up to $5 \%$ of the body weight. Therefore, cod get infected with larvae already as young fish, and their number consistently increases as time goes by. Acanthocephala species occur in cod from the southern Baltic usually in small numbers (Studnicka 1965, Rokicki 1975, Reimer and Walter 1993). In recent years a decrease of infection with Gammarus spp. by Pomphorhynchus laevis has been observed. Sulgostowska and Vojtková (1992) did not find a single P. laevis larva in 863 Gammarus spp. individuals. Similar observations were made by Voigt (1991) during his research carried out in the eastern Baltic. This probably explains why only two specimens of $P$. laevis were found in young Baltic cod in the present study.

Table 3

The mean percentage of different diet components in Baltic cod of various length according to Załachowski 1977 (amended)

\begin{tabular}{|c|c|c|c|c|c|}
\hline \multirow{2}{*}{$\begin{array}{l}\text { Sustenance } \\
\text { component }\end{array}$} & \multicolumn{5}{|c|}{ Length class $[\mathrm{cm}]$} \\
\hline & $5-15$ & $16-25$ & $26-35$ & $36-45$ & $46-55$ \\
\hline Priapulida & 0.1 & 0.1 & 0.1 & & \\
\hline Polychaeta & 39.9 & 40.0 & 35.5 & 25.5 & 12.9 \\
\hline Bivalvia & & & & 0.1 & \\
\hline Entomostraca & 0.1 & & & & \\
\hline Mysidacea & 23.9 & 19.2 & 8.6 & 5.0 & 3.4 \\
\hline Amphipoda & 13.9 & 11.8 & 3.8 & 1.1 & 0.2 \\
\hline Cumacea & 1.2 & 2.5 & 0.3 & 0.1 & 0.1 \\
\hline Isopoda & 5.9 & 14.2 & 23.7 & 24.2 & 20.1 \\
\hline Decapoda & 4.4 & 2.7 & 5.0 & 3.6 & 1.2 \\
\hline Clupeidae & & 1.0 & 13.4 & 31.7 & 50.9 \\
\hline Gadidae & & & 0.2 & 1.0 & 3.8 \\
\hline Gasterosteidae & & & & 0.4 & \\
\hline Ammodytidae & & & 0.1 & 0.7 & 2.6 \\
\hline Gobiidae & 9.6 & 7.6 & 6.7 & 3.5 & 1.5 \\
\hline Cottidae & 0.1 & & & & \\
\hline Pleuronectidae & & & & & 0.2 \\
\hline Others & 0.9 & 0.9 & 2.7 & 3.3 & 3.1 \\
\hline
\end{tabular}




\section{REFERENCES}

Buchmann K., 1988. Variation of the infection level of Echinorhynchus gadi (Acanthocephala) in Baltic cod (Gadus morhua). Bulletin of the European Association of Fish Pathologists 8: 11-14.

Buchmann K., 1995. Ecological implications of Echinorhynchus gadi parasitism of Baltic cod (Gadus morhua). Journal of Fish Biology 46: 539-540.

Fagerholm H.P., 1982. Parasites of fish in Finland. Acta Academia Aboensis. B 40 (6): 40-43.

Fagerholm H.P., 1987. Gammarus oceanicus (Crustacea: Amphipoda) as an intermediate host of Hysterothylacium auctum (Nematoda: Ascaridoidea); Life-cycle and taxonomy of the parasite. Information of Institute of Parasitology Åbo Akademi 19: 30.

Køie M., 1993. Aspects of the life cycle and morphology of Hysterothylacium aduncum (Rudolphi, 1802) (Nematoda, Ascaridoidea, Anisakidae). Canadian Journal of Zoology 71: 1289-1296.

Mańkowski W., 1959. Dorsz bałtycki (jego biologia, połowy i technologia). [Baltic cod (its biology, fishing and processing technology).] Gdańskie Towarzystwo Naukowe, Gdańsk. (In Polish.)

Markowski S., 1933. Die Eingeweidewürmer der Fische des Polnischen Balticums (Trematoda, Cestoda, Nematoda, Acanthocephala). Archives d'Hydrobiologie et d'Ichthyologie 7: 1-58.

Morozińska-Gogol J., 1995. The role of cod, Gadus morhua L. in the life-cycle of Contracaecum osculatum (Rudolphi, 1802) (Nematoda, Anisakidae)-an overview. Meddelande Fran Havsfiskelaboratoriet 327: 123-130.

Myjak P., Szostakowska B., Wojciechowski J., Pietkiewicz H., Rokicki J., 1994. Anisakid larvae in cod from the southern Baltic Sea. Archive of Fishery and Marine Research 42 (2): $149-161$.

Reimer L.W., 1995. Parasites especially of piscean hosts as indicators of the eutrophication in the Baltic Sea. Applied Parasitology 36: 124-135.

Reimer L.W., Walter U., 1993. Zur Parasitierung von Gadus morhua in der südlichen Ostsee. Applied Parasitology 34: 181-186.

Rokicki J., 1975. Helminth fauna of fishes of the Gdańsk Bay (the Baltic Sea). Acta Parasitologica Polonica 23 (2): 37-84.

Rutkowicz S., 1963. Wyniki badań nad stadem dorsza (Gadus callarias L.) południowowschodniego Bałtyku w latach 1946-1960. (Dynamika stada na tle biologii i ekologii gatunku). [The results of a study on a cod population (Gadus callarias L.) of the southeastern Baltic Sea within 1946-1960. (The population dynamics in relation to the biology and ecology of the species).] Studia i Materiały Morskiego Instytutu Rybackiego w Gdyni A 12: 165-211. (In Polish.)

Studnicka M., 1965. Internal parasites of the cod, Gadus callarias L., from the Gdańsk Bay of the Baltic Sea. Acta Parasitologica Polonica 13 (28): 283-290.

Sulgostowska T., Vojtková L., 1992. The helminth fauna of Gammarus spp. (Amphipoda) from the south-east Baltic Sea (Poland). Acta Parasitologica 37 (4): 189-193.

Valtonen E.T., Van Maren M.J., Timola O.,1983. A note on the intermediate hosts of Echinorhynchus gadi Zoega, in Müller (Acanthocephala) in the Baltic Sea. Aquilo Seriologica Zoologica 22: 93-97. 
Voigt M.O.C., 1991. City structure of the helminth parasite fauna of gammarids (Crustacea: Amphipoda) in Kiel Bay, western Baltic Sea. Meeresforschung 33: 266-274.

Załachowski W., 1977. Ilościowa i ekologiczna analiza pokarmu użytkowanego przez populację dorsza w Południowym Bałtyku. [A quantitative and ecological analysis of sustenance used by the cod population in the southern Baltic]. Rozprawy, Akademia Rolnicza w Szczecinie No. 53. (In Polish.)

Received: 14 October 2004 Accepted: 13 December 2004 